\title{
Viseme and Its Teaching Strategy for Speech-Reading and Language Normalization of People with Hearing Loss
}

\author{
SoHyun Cho', ChamDo Choir \\ ${ }^{1}$ Department of Speech Pathology and Audiology, Sehan University, Yeongam, Korea \\ ${ }^{2}$ The Korean Oral Decipering Institute for Nonverbal Speech, Seoul, Korea

\section{청각장애인의 독화/판독과 언어 정상화를 위한 독화소 및 독화교수전략} \\ 조 소 현 $\cdot$ 최 참 도 ${ }^{2}$ \\ 세한대학교 언어치료청각학과', 한국어무성발화판독연구소(KODINS) ${ }^{2}$
}

\begin{abstract}
The social awareness of "the language of the hearing impaired, ie., manual sign language," is prevalent today. However, this false proposition has deepened the error and prejudice that deaf should be taught sign language from early childhood and should be taught by sign language in all educational curriculums. As a result, it impossible for us to live only in the community between the deaf and the deceased in the basic language life as a citizen who listens, reads, or writes in korean and they limit the potential for deaf children to compete equally with the general public. However, in order to understand the language and vocabulary of the mother tongue through dealing with the viseme of Korean, it is necessary to understand the language and language of the mother tongue and to communicate with the neighbors through traditional oral education. Through this study, it is shown that all the hearing impaired people in Korea, including the deaf people who only have to communicate through sign language, can learn the poetry by the Korean viseme system. The purpose of this research is to establish a curriculum for lifelong education that adapts to the general society, lives with the general public and enhances their competitiveness according to individual creativity through application of the system in our study.
\end{abstract}

Key Words: Viseme, Korean viseme system, Lifelong education curriculum.

Received: September 24, 2018 / Revised: October 15, 2018 / Accepted: October 16, 2018

Correspondence: SoHyun Cho, Department of Speech Pathology and Audiology, Sehan University, 1113 Noksaek-ro, Samho-eup, Yeongam 58447, Korea Tel: +82-61-469-1317 / Fax: +82-61-469-1317 / E-mail: signalwh8540@hanmail.net

\section{INTRODUCTION}

오늘날 농아들의 유일한 언어는 수화라는 게 보편적인 사회 적 인식이다. 이 잘못된 명제로 인해 농아들을 위한 교육과정 에 수화는 필수이고, 이로 인한 사회적인 편견이 뿌리 박혀 건강 한 사회의 구성원으로서의 소통을 통한 역할이 제한되고 있는 게 사실이다. 그러나 농아들도 구화교육을 통해 모국어를 사용 하는 일반인들과의 교제가 가능하며 특히 독화소의 습득을 위 한 훈련을 하게 된다면 그들의 재능을 충분히 발휘할 수 있다.

(c) This is an Open Access article distributed under the terms of the Creative Commons Attribution Non-Commercial License (https://creativecommons.org/licenses/by-nc/4.0) which permits unrestricted non-commercial use, distribution, and reproduction in any medium, provided the original work is properly cited. 독화소(viseme)는 특정한 소리를 묘사하는 데 사용될 수 있 는 포괄적인 안면부의 시각적 영상 특징을 의미한다. 독화소는 구어에 있어서의 이 소리와 저 소리를 다르게 구별할 수 있는 청각적인 소리의 최소 단위인 음소(phoneme)와 대응되는 시각 적인 최소 단위를 말한다. 이 독화소를 사용하면, 청각장애인들 도 소리를 시각적으로 들을 수 있다고 역설적으로 표현하는 학 자들이 적지 않다. 예를 들어, 청각장애인들이 상대방의 말을 읽을 때(독화, speech-reading), 저 말소리와 이 말소리가 같고, 저 말과 이 말이 다르다는 것을 구별할 수 있는 요소를 독화소 라고 할 수 있는데, 그렇다고 독화소와 음소가 1:1로 대응하거 나 그 단위들을 공유하지는 않는다. 간혹 몇몇의 음소들은 / 크, 그, 응 $(-n g)$ 과 같이 발음할 때나 안면부를 쳐다볼 때 모두 동 
일하게 /ㅋ/처럼 보인다든지, /츠, 쉬, 즈, 스, 쓰/들을 각각 발음 할 때에도 역시 안면부의 독화소로서는/ㅉ/와 대동소이하게 인지될 수 있으며, 또한 /트, 드, 느, 르/ 등 잇몸소리 자음들을 발음할 때에도, 모두 독화소 /트/와 비슷하게 인식하며, 양순음 인 /프, 쁘, 므/와 같은 것들도 독화소 /브(b)/와 대동소이하게 보여서 이들 각 묶음의 말소리들을 독화하여 시각적으로만 구 별하기는 쉽지 않은 일이다.

그래서 [펜, 벤, 멘]과 같은 무의음절 군이나 [멍멍, 벙벙, 펑 펑, 뺑뻥]과 같은 의음단어들도 모두 독화소로서는 변별력이 크지 않아서 시각적으로만 변별하려 할 때 혼돈을 일으키기 십 상이다. 즉, 독순-판독자들에게 있어서 동일 조음 계열의 자음 이 같은 모음과 받침구조를 지닌 음절이나 단어들은 변별하기 어려운 과제에 속한다.

이러한 난해한 과제들을 발음한 구형 사진 한 장만으로 정확 히 포착해 낸다는 일은 독화훈련교육 자료로서는 적절하지 못한 자료 제시법이라 할 수 있다. 실제 말하기 대화 장면 중에 주어진 동작의 시각적 '특징'을 자료로 활용하여 시간적(timing) 차이와 지속성(duration)의 미묘한 차이들을 감지해서 독화/판독할 수 있게 하는 교육훈련이 절대적으로 필요하다.

따라서 본 논문에서는 국내 독화교육이나 독화 전문가들이 전무하고 이와 관련된 논문이 없는 열악한 현실 속에서 독화의 효용이 점차로 늘어나리라는 미래지향적 예견에 의해, 지금이 라도 독화교육을 통한 전문가 양성을 위한 그 시발점으로 삼고 자 조금은 체계적이지 못할지라도 독화교육의 필요성과 그 유 의성을 알리기 위해 독화소 훈련자료를 위한 사전 연구들을 안 내하는 기초자료로 삼고자 하였다.

\section{MATERIALS AND METHODS}

\section{음소의 최소대립의 쌍(minimal pairs)과 독화소 훈련자료}

최소대립쌍(minimal pairs: 最小 對立雙)이란 어떤 언어에 있어서 한 말소리에 음운적인 차이가 있는지를 분석하기 위해 이용하는 두 개의 단어를 말한다. 예를 들면 한국어의 '탈(/ $\left.\mathrm{t}^{\mathrm{h} a l} /\right)^{\prime}$ 과 '딸(/tal/)'을 비교하면 '알(/al/)'은 공통 항으로 갖고 있 지만 ' $E\left(/ \mathrm{t}^{\mathrm{h}} /\right)^{\prime}$ 와 'ㄸ $(/ \mathrm{t} /)^{\prime}$ 가 달라서 의미를 구별한다. 이러한 한 부분만 다른 한 쌍의 단어들을 최소대립쌍이라고 한다. 한국어 에서는 $/ \mathrm{t}^{\mathrm{h}} /$ 과 $/ \mathrm{t} /$ 를 구분하지만 다른 언어에서도 꼭 그렇다고 할 수 없다. $/ \mathrm{t}^{\mathrm{h}} /$ 와 $/ \mathrm{t} /$ 가 구분되지 않는 언어 환경에서 자란 사 람은 '탈'과 '딸'을 구분하지 못하고 같은 소리로 인식할 것이다. 그래서 최소대립쌍은 외국어 교육에서 많이 쓰이지만, 원래 음 성학과 음운론을 공부하는 대학원 학생들에게 많이 교수되던 개념이다. 청각장애 구화교육의 청능훈련과 독화교육 및 판독 을 위한 교수에서는 음소의 최소대립쌍의 개념을 독화소로 대
체하여 눈으로 음소를 변별하기 쉬운 것과 어려운 것들을 알맞 게 훈련어휘로 배열하고 대립시키는 자료로 구성하기 위한 기 초 준거로 사용된다.

\section{영어 음소 최소대립쌍 단어들}

영어에서는 이러한 알파벳에 의한 최소대립쌍의 차이가 명확 히 드러난다.

서로 다른 두 개의 소리 $\mathrm{A}, \mathrm{B}$ 가 하나의 음소인지 별개의 음 소인지 판별할 때 흔히 최소대립쌍(다른 조건은 동일, 하나의 소리만 차이남으로 두 단어의 의미가 달라지는 단어 짝)과 상 보적 분포를 이용(말소리가 동일한 환경에서 실현되지 못하는 경우, 배타적 분포를 이룬다고 함), 배타적 분포를 이루고 있는 말소리들이 합해서 하나의 음소를 이루면 이 말소리들은 상보 적 분포를 이룬다. 두 소리가 최소대립쌍을 지니면 당연히 별개 의 음소인데, 그 출현 분포가 서로 겹치면 두 소리는 별개의 음 소일 가능성이 무척 크다. 물론 아닐 가능성도 있지만 말이다 (예: 북-붓). 반면 두 개의 소리가 최소대립쌍도 지니지 않으면 서 상보적 분포를 이룬다면 한 음소의 이음(allophone, 변이음) 일 확률이 높다. 그렇다면 두 개의 소리가 최소대립쌍도 지니지 않으면서 상보적 분포를 이루면 한 음소의 변이음일 확률이 낮 아지는 것은 아닌가 하는 의문에 대해 답을 한다면, 음소의 변 이음 조건은 변이음의 변화로 인한 최소대립쌍이 없어야 하고 분포가 상보적이어야 하는데, 이 조건을 만족한다면 하나의 음 소일 확률이 높다. 여기다가 음성학적 자질까지 유사하다면 사 실상 하나의 음소의 변이음이 되는 것이 옳다. 그렇다면, "두 개 의 소리가 최소대립쌍을 지니지 않으면서, 상보적 분포를 이루 지 않는다면 어떻게 되는 것인가?” 하는 문제의식에 대해서는 다음과 같이 대답할 수 있다. 예를 들어 자전거에서 “”을 누군 가는 경구개음으로, 누구는 치조음으로 읽는 사람이 있는데, 이러할 때는 최소대립쌍이 없다. 즉, 뭐라고 발음해도 의미 변 화는 없으니까 그렇다. 둘 다 초성에 나타나므로 상보적 분포는 아니다. 이런 경우를 임의적 변이음이라고 한다. 일반적인 경우 는 아니지만, 반면 우리가 보통 말하는 변이음은 결합적 변이 음이라고 한다.

\section{한국어 독화소 및 독화어의 대립적 난독 목록}

시각적인 변별력 증진이 대단히 중요하므로 시각적인 최소가 청역치라는 청각학적 용어와 대칭되는 시각적인 용어 최소가변 역치(minimum distinguishable threshold)를 사용하여, 먼저 의미 있는 소리의 최소단위인 최소가청역치 vs. 변이음을 뒤섞 은 “최소가변역치”를 가장 잘 예증해 주는 어음리스트를 만들 필요가 있다. 청각적으로 변별할 수 있도록 검사하는 청각학적 어음리스트로 측정한 최소가청역치에 해당되는 어음청취역치 
(speech recognition threshold)와 독화소로서의 독화판독을 객관화할 시각적 최소가변역치 사이에 존재하는 동일함과 유사 함, 동질성과 이질성의 차이는 어떤 것인지에 대해서는 세밀한 탐색이 필요하다. 그러나 독화소 대립 쌍 중 그 유사성이 커서 독 화에 어려움을 줄 수 있는 목록(Appendix)을 제시해 보았으나 이 난독 목록의 타당도는 앞으로 실제 독화판독 훈련교육과 평 가 등의 잘 구조화된 실험연구를 통해 더 잘 입증되고, 보완 연 구과정을 거쳐야만 하는데 이러한 사실은 사람과 사람이 대면해 서 대화하는 것에 비해서 전화상으로 말하는 경우 청취해독의 오류가 더 흔하게 많이 생기는 사실로서 잘 설명될 수 있다.

어떤 언어학자들은 청각과 시각 양방향 모델을 통해서 최상 의 이해를 얻는다는 주장을 하거나, 또한 만일 이 두 영역 중에 하나를 잃는다면, 언어수용의 이해력은 떨어지게 마련이라고 주장하기도 한다. 그리고 이들의 또 다른 말소리 지각에 대한 청각과 시각의 상대적 기여 현상에 관한 연구에서, 참가자들은 특정 음절(예를 들어, 'ba')을 발화하는 소리를 동시에 보는 영 상을 제공받으면서, 다른 음절(예를 들어, 'ga')과 관련된 입술 동작이 그와 동시에 일어나는 것을 듣고 보는 실험에서 다수의 참가자가 다른 음절(예를 들어, 'da')을 들었다고 보고했는데, 이는 사람들이 듣는 소리가 그들이 본 입술 동작에 의해 영향 을 받을 수 있음을 증명하는 것이었다. 그 효과는 사람들이 자 신들이 보고 있는 것과 듣고 있는 것이 다르다는 것을 알고 있 을 때조차도 발생하는데, 이는 시각과 청각의 통합이 자동적으 로 그 사람의 인지심리 속에서 작동하며, 새로운 지각을 일어나 게 한다는 점을 보여준다. 때때로 영어권에서, 독화소들의 배열 에 따라서는 독화에 의존하는 농인들이 "elephant juice(코끼리 주스)"라는 구절을 말했을 때 독순으로 "I love you."라고 잘못 읽은 경우를 곧잘 익살스럽게 예화로 드는 것과 딱 일치하는 웃지 못할 사례들이 얼마든지 일어날 수 있다. 독화소 연구를 위해서 적용될 수 있는 연구 분야에는 주로 어음처리와 어음인 지 및 컴퓨터 안면부 촬영 동영상 등이 포함되어 있다.

\section{독순(입술읽기; Lip-reading)}

독순 혹은 독화로 알려진 입술읽기란 정상적인 말소리들이 기능하지 못할 때, 문맥과 언어지식 그리고 어느 정도라도 잔존 해 있는 청력들에 의해 제공된 정보에 의존하여, 양 입술과 얼 굴 및 혀의 움직임들을 시각적으로 해석함으로써 말을 이해하 게 하는 하나의 기술이다.

원초적으로는 농과 난청인들에 의해 사용되어 온 기능이기 는 하지만, 일반적으로 정상청력을 지닌 이들도 하위 의식 수준 (subconscious level)에서 움직이는 입모양으로부터 시각적 정 보를 함께 활용하곤 한다. 이 연구는 입술읽기를 잘하는 농인 독화자들로부터 주의를 끌고 주목받았으면 한다. 일상의 대화
과정에서 정상적 청·시력과 사회기술을 지닌 이들에게도 언어 의 청각적 이해와 유창한 화자가 되기 위한 보조수단으로써 입 술과 안면부로부터 하위 의식적으로 어느 정도까지는 독화를 보조수단으로 활용하여 정보를 활용하게 된다. 이는 각 말소리, 즉 음소들마다 특별한 안면부 및 구강부의 특징(독화소)을 갖고 있기 때문이다. 따라서 사람들은 음소가 비록 그 음향이 별로 소용에 닿지 않거나 주변 소음 등으로 인해 청취의 질이 떨어지 는 한이 있더라도, 시각적 단서들의 바탕에서 무엇을 어떻게 생 성하는지를 어느 정도 추론해 낼 수 있다. 독순이란 음성언어를 듣고 있는 동안에 풍성한 시청각적 단서들을 언어 학습을 위하 여 우선적으로 제공해 주는 일이라 하겠다. 이와 같은 생각은 생후 4 8개월 된 아기들이 말하기를 학습하는 데 있어서 자연 발생적이거나 혹은 자연발생적이 아닌 언어를 학습하는 데 있어 서도 구강부의 움직임에 특별한 주의를 기울이고 있다는 점을 분명히 연구한 르코비츠와 한센-티프트(Lewkowicz \& HansenTift, 2012)에 의해 입증된 바 있다. 12개월 이후에는 자연언어인 모국어를 들었을 때 더 이상 입 부분을 보려고 하지 않아도 시 청각적 단서들을 충분히 획득하게 된다. 모국어가 아닌 또 다른 언어를 들어도 발화를 처리하고 이해하고 또 생산하기 위하여 시각적으로도 청각적으로도 맞물려 작용하도록 변환시키는 일 을 촉진시켜 간다.

이 연구는 기대했던 대로, 농아 성인들은 정상청력을 가진 성인들보다 말을 이해하기 위하여 독순을 더 잘하게 되면 될수 록 입술읽기에 의존하는 일이 더 많아진다는 사실은 그들이 독 화와 독순의 연습에 더 많은 시간과 노력을 증가시켜 왔다는 사실에 기인한다고 본다. 그럼에도 같은 연구 팀들은 청각장애 어린이들과 정상청력 아동들 간에 똑같은 실험연구를 시행했 을 때, 두 집단 간 입술읽기의 기술에 차이가 없다는 것을 연구 결과로 밝혀냈다. 14 살 이후는 농 아동이나 정상청력 아동 사이 에 기술의 수준들은 의미가 분명하게 차별화되기 시작하며, 초 기 생애의 독순기술은 청각 용적(auditory capability)과는 독립 적인 것이라 함을 지지해 준다. 이 사실은 정상청력인들의 독순 기술의 저하를 지적해 주는 일일 수 있거나 혹은 농인들은 연 령별로 입술읽기의 기술이 효율적으로 증가했다는 것을 지적 해 주는 결과라고 본다. 실제적인 대화가 이루어지고 있는 상황 에서 독화하는 일은 대뇌의 시각중추만이 아니라 똑같이 청각 중추까지도 활성화시킨다는 점이 증명되고 있다(Lee, 2008). 다감각적인 상호작용을 통해서, 대뇌의 서로 다른 영역들을 오 히려 윤곽이 더 뚜렷하게 드러내 보이게 한 이 연구로 다감각 간 조정을 위한 노력이 서로 다른 감각들에 대해 기여케 함으 로써 대뇌가 바람직하게 활성화된다고 한다. 독화는 제한적이 지만, 그럼에도 많은 음소들 중에서 동일한 독화소로 할당이 되어 있어서, 시각적 정보 자체만으로 구분한다는 것은 불가능 
에 가깝다. 사람의 조음 위치가 시각적으로 그 조음 위치와 조 음 양식을 간파하기에는 대부분의 혀의 동작들이 구강 혹은 후두부 안쪽 깊은 곳에서 이루어지기 때문이다. 유성음과 무성 음의 짝들은 무성자음 [피]와 [ㅂ]]에 유성자음 [ㅂ(b)], 그리고 무 성자음 $[\exists]$ 와 $[\neg]$ 에 유성자음 $[\neg(\mathrm{g})]$, 무성자음 $[\mathrm{E}]$ 와 [ᄃ]에 유 성 자음화된 [ᄃ(d)]는 물론 한국어에는 없는 영어 음소의 경우 무성자음 [f]와 유성자음 $[\mathrm{v}]$ 및 무성 마찰자음 $[\mathrm{s}]$ 와 유성자음 [z], 이와 마찬가지로 비음 [⒨] 대 유성 양순음 [ㅂ(b)]) 등의 예와 같은 유성자음 vs. 무성자음의 짝들도 유사 독화소로서 변별이 어려운 독화소의 짝이 된다고 설명할 수 있다. 영어의 경 우 시각 단독으로 변별할 수 있는 것은 말소리 중에서 30 40\% 정도밖에 되지 않는다고 평가되고 있다. 그러므로 예를 들어, "Where there's life, there's hope. (생명이 있는 곳에 희망이 있 다.)"라는 관용구를 독화할 때에, 마치 “Where's the lavender soap? (어디에 라벤더 비누가 있어요?)”라는 말로 혼돈하여 독 화하기도 한다. 대부분의 영어 사투리 사용자들 중에 흔히 일 어나는 혼돈이지만 독화 상황에서는 더욱 심각한 일이 벌어질 수 있다. Kisor(2010)는 “What's That Pig Outdoors?"라는 표 제로 출간한 그의 체험적 회고록에서 농 문제로 인한 체험에서 청각적 청취오류의 예로 “What's that pig outdoors?"라는 질 문을 듣고 그 자신은 “What's that big loud noise?”라는 말로 잘못 들었다고 회고하며 재미있는 농인의 구어생활 체험담을 소개했다. 그는 이 표제의 체험을 중심으로 독화의 불충분한 문제점들에 대해 토론했다.

결론적으로 독화자는 주변 환경으로부터, 의사소통 문맥으 로부터 단서에 단단히 입각해서 또한 어떠한 일들에 대해 이야 기를 나누고 있을까 하는 지식의 단서들 위에 단단히 기초해야 만 한다. 일상적으로 나누는 인사들이나 친숙한 화제를 가지고 하는 관련된 연결 담화들과 같이 관용적인 어구들을 독화하기 는 비교적 용이하지만, 관계 고립적인 상황에 불쑥 튀어나온 발 화들이나 전혀 만나 본 적이 없는 사람의 이름이나 지명이나 단어들과 같이 사전 정보 지원이 없이 나오는 발화를 독화하기 란 그렇게 만만치 않으며, 우스꽝스러운 농담으로 치부되는 숱 한 일화의 주인공이 될 수 있다는 사실을 알아야 한다.

\section{독화에 곤란을 주는 난관 시나리오}

첫째로는 화자의 입술의 명료한 시각상의 부족; 이 점은 다 음과 같은 문제들이 포함된다. 1) 콧수염이나 입을 손으로 가리 거나 하는 방해요소들, 2) 화자가 머리나 고개를 이리저리 돌리 거나 내리거나 하는 버릇들, 3) 밝기가 어두운 주변 환경일 때, 4) 화자의 등 뒤에 창문이 있어 밝은 빛이 비쳐져서, 안면부가 어둡게 보일 때 등이다. 두 번째로는 다수의 사람들이 빠르고 연속적으로 말해 대는 집단 토론 장면이다. 어디를 보아야 할
것인지를 아는 것 자체가 바로 도전이기 때문이다. 마지막으로 화자가 이상한 말의 리듬과 운율과 음정으로 말할 때는 독화가 곤란하다.

\section{독순/독화 연습을 위한 조언들}

독순/독화 연습를 위한 조언들을 종합해 보면 다음과 같다. 독화를 위해 쉽게 변별적으로 구분할 수 있는 어음들은 $30 \%$ 에 불과하다. 나머지 $70 \%$ 는 맥락 단서들을 동원하여 추론해야 한다는 것 자체가 어려움이다. 이렇게 독화할 수 있는 별로 안 되는 요소들로 점차 조금씩 더 쉬워지는 과정으로 만들어야 할 필요가 있다. 바로 독화/판독훈련의 교육과정이다. 입술읽기 를 배우는 일은 책읽기를 학습하는 과정과 비슷하다. 입술읽기 의 초보자는 하나하나의 말소리에 집중하기 때문에, 그 의미를 놓친다. 마지막으로 개개의 말소리보다 전체적 전언으로 수용 하는 게 훨씬 효과적으로 독화될 수 있다.

말하는 화자에게 독화를 돕기 위한 발화조건 및 환경적 조언들

독화자 및 발화자 어느 한편이나 상호작용의 관점에서 보면 다음과 같은 점에 주의하여야 한다. 1) 당신의 입술을 안면부가 명료하게 보이도록 확실히 말해 주도록 노력하라, 2) 입술모양 을 과장하지 말고 너무 천천히 말하려고 의식적으로 노력하지 말라, 3) 가급적 조용한 환경 및 좋은 밝기 환경에서 독화하도 록 배려해 주어야 한다, 4) 주변에 시각적 방해 요소들을 치우 고 단순한 환경이 되도록 노력하라, 5) 창문이나 불빛이 말하는 이의 등 뒤에서 비쳐오지 않도록 하라, 6) 전등이나 빛이 당신 이 독순하려는 대상이 아닌 당신 등 뒤에 놓이도록 확실히 배 치하라, 7) 말하는 자의 얼굴을 독화자가 분명하게 볼 수 있다 는 확신 속에서 말해 주도록 하라, 8) 만일 당신이 잘 알지 못 하는 화제들을 대화할 때에는 명확하게 확인 질문하도록 하 라, 9) 알맞은 밝기와 시각적인 방해물들이 많지 않은 조용한 환경 속에서 대화를 유지하라, 10) 말하는 이에게 그의 얼굴로 부터 그의 손이나 다른 물체들을 치워야 함을 알게 하라, 11) 화 자가 입모양을 과장하거나 너무 크게 말한다든지 하면, 정상적 으로 자연스럽게 말해줄 것을 정중히 요청하도록 하라, 12) 사 람들이 당신의 입장을 깜박 잊었거나 당신으로부터 아래를 바 라보거나 시설물로부터 가려지는 경우에는 그의 안면부를 잘 볼 수 있게 해달라고 정중히 부탁하라, 13) 당신이 되풀이 말해 줬어도 여전히 이해하지 못한다면, 화자가 다른 말로 바꾸어 표 현해 달라고 요청하라(rephrasing/paraphrasing).

\section{독화교육의 원리와 방법}

독순은 구어에 대한 그들의 경험을 더 발전시키기 쉽게 만드 는 하나의 기술이다. Doucet et al.(2003)의 연구에 의하면 진행 
성 농인 성인들이 돌연성 농인들보다 훨씬 더 독화를 잘할 수 있다고 한다. 일리가 있는 연구결과이며, 이 결과는 독화교육에 많은 시사점을 남긴 바 있다.

입술읽기를 학습하는 일은, 독화가 분명히 가르쳐질 수 있는 교과목이 될 수는 있지만, 영유아들은 우선적으로 태어나서 6 12개월이면 스스로 입술읽기를 시작하고 있음을 관찰할 수 있다. 그 입술모양을 흥내 내려고 아기는 그들이 듣는 말소리와 일치시켜서 자신의 입모양을 학습하고 있음이 분명하다, 새로 탄생한 신생아라 할지라도 혀를 입 밖으로 날름거리는 동작이 나, 입술을 벌리는 동작 등 그들의 입 동작은 성인의 동작을 모 방하려 하는 것을 보여준다. 이것이 이후의 모방 동작과 독순 능력에 대한 전조적인 동작이라고 할 수 있을 것이다. 4 개월 정 도 된 영아들은 시각과 청각 정보들을 연결하는 능력을 갖고 있어서 이 능력이 입술읽기를 학습할 때에 도움이 될 수 있다. 예를 든다면, 아기들에게 녹음된 음향으로 청각적 자극을 들려 주면서 동시에 시각적 자극을 제시했을 때 아기들은 시각적 자 극을 더욱 오랫동안 쳐다보려고 하는 경향이 있다는 점을 보여 주는 연구가 있었다. 이러한 신생아로부터 영유아의 독화 독순 에 관한 생래적인 학습능력을 인정한다고 할 때, 우리는 청각 장애인을 위한 독순독화의 훈련교육과정에 대한 타당도를 더 욱 높이 입증할 수 있을 것이며, 이러한 독화교육과정이 음성학 적, 음운론적 관점에서는 물론 시각적 독화소론적인 체계에서 바르게 세워져야 할 당위성을 획득할 수 있게 된다. 독화에 대 한 새로운 연구 중에는 독순의 관점에서 자폐성 장애 문제의 시 각적 기호의 적용 문제에 대한 검토를 접근할 수 있게 한다. 플 로리다의 애틀랜틱 대학교의 연구(Lewkowicz \& Hansen-Tift, 2012)는 독순능력을 검사하고 있는 성인 집단에게 생후 12 개월 된 영유아 집단을 비교연구의 대상으로 접근했다. 서로 다른 발달단계에 있는 다양한 연령층의 말하기를 할 때 그들의 입모 양을 눈으로 보도록 영유아들과 성인들의 역할을 서로 바꾸어 가며 하도록 해서 그 결과를 토론하게 하였다.

생후 4개월 된 영아들은 전형적으로 말을 이해하기 위하여 눈의 초점을 맞추고 집중한다. 그리고 6 8개월 사이의 영유아 들은 언어 획득 초기의 '옹아리' 시기를 맞아 말하는 이의 입모 양에 초점을 맞추는 변화가 일어난다. 그들은 생후 10 개월이 될 때까지 입술읽기를 계속하면서 그들의 주의와 시선이 닿지 않는 후방까지 시선을 바꾸어 집중하도록 하였다. 그 결과 대상의 말 하기가 출현하기 시작하였고, 이러한 출현은 '사회적 단서들'을 더 잘 이해할 수 있는 능력과 연관된 이 발달의 제 2 단계로 칭하 였고 이러한 능력은 의미를 붙이고 자기 신념과 갈망들을 더 잘 이해하게 만드는 능력들과 깊은 연관이 있다고 해석하였다.

그들의 자연어(모국어)와 또 다른 언어를 들을 때 영유아들 은 그들이 현재 도달한 학습 획득 단계임에도 불구하고, 그들
의 주의가 다시 입술읽기로 되돌아가, 약 12 개월 정도까지 입술 읽기를 계속하게 된다. 그들의 자신만만한 주장을 지지할 수 있 으려면 더욱 많은 연구들이 필요하다고 생각되지만 그럼에도 불구하고 그들의 자료들은 " 12 개월이 된 영유아라면 나이에 적 절한 지각과 인지기능을 발달시키기 어려울 수도 있을 것이며, 자폐성 장애와 비슷한 장애 문제들로 인한 위기에 직면할 수도 있을 것”이라는 점을 시사해 주고 있다. 입술읽기는 태어나서 얼 마 되지 않은 어린 시기부터 아기들에게 발달되는 자연스러운 능력 중 하나이기 때문에 사람들에게 독순법은 교수될 수 있으 며, 누구나 연습에 의해 더 훌륭한 독순자들로 향상될 수 있다. 사람들이 독순하기를 배우고 싶어 할 때 훈련사들이나 교사들 은 독순방법을 배우도록 도와줄 수 있을 뿐 아니라, 어떤 확실 한 맥락에 초점을 두어 집중해야 할지 가르쳐 주고 학습을 도 울 수 있다(Choi, 2008).

독순법을 가르치거나 향상시킬 수 있는 몇 가지 사항들로서 는 1) 당신의 눈으로 귀가 하는 일을 도와줄 수 있도록 훈련하 라, 2) 입 부위 그리고 치아와 혀의 움직임을 주시하도록 하라, 3) 말하는 사람의 얼굴 표정을 함께 읽도록 하라, 4) 말하는 이 의 몸짓 언어들도 주시하라, 5) 잔존청력을 최대한 활용하라 등 이 있다.

\section{독화의 효용이 점차 늘어나리라는 미래지향적 예견 (anticipation)}

농인들에 의해서 독화하기가 사용되는 일은 농으로 태어나 자라나는 독화자들이 구어를 듣는 일은 결코 없을지도 모르며, 또한 구어의 유창한 사용자들이 되는 일도 별로 있을 법하지 는 않지만, 그럼에도 그것들보다 훨씬 더 어려운 남의 말을 읽 어내는 독화를 해 낸다는 사실을 주목해야 한다. 이들은 역시 교육적인 환경에서 의식적인 훈련에 의하여 개개인의 독화소들 을 학습해야만 그것이 가능해진다. 덧붙여 독화하는 일은 여러 가지 많은 상황들에 초점을 동시에 맞추어야 하며, 따라서 독 화하는 과정에서 극도로 피로해질 수밖에 없다. 그러한 이유들 때문에 많은 농인들이 마임이나 제스처, 글씨 쓰기, 또는 수화 통역자 보기 등과 같이 많은 의사소통 채널들을 주목해야 하 는 것처럼 보이지만, 농인들 중에는 비수화적 의사소통으로서 독화통역을 더 선호하고 사용하기를 좋아하는 이들도 많다는 사실을 명심해야 한다. 도로시 클레그(Clegg, 1953)의 저서 "주 의 깊게 듣는 눈(The Listening Eye)"에서 인용한 다음의 표현 을 음미할 필요가 있다. "당신은 코르크 뚜껑으로 잘 막힌 유리 병 안에서 살고 있는 농인이 되었다. 그 병 속에서 바깥세상을 넚을 잃고 바라보지만, 그러나 그 세상 안으로 당신에게 도달할 수 있기란 쉽지 않다. 입술읽기를 학습한 이후에 코르크 마개 는 바깥을 향해 열려져 있지만 당신은 여전히 유리병 속에 머 
물러 있으려 한다. 코르크 마개가 열려졌지만, 외부 세계는 너 무나도 느리게 당신에게로 들어올 것이 분명하다.” 이상과 같이 독화는 어렵지만 성공적일 수 있다는 견해는 농인들의 세계 안 에서 상대적이고 비교적인 논쟁상의 의견일 뿐이다. 왜냐하면 이러한 논쟁의 불완전한 역사는 늘 구화주의 대 수화주의의 논쟁의 그늘 속에서 존재할 것이기 때문이다. 그러나 독화를 활용하고 있는 농인들과 대화를 할 때에 과장된 구강부 동작으 로 말해 준다면, 시각적인 언어이해에 별 도움이 안 될 것이며, 사실상 유용한 단서들을 오히려 훼방하는 일이 될 수 있다. 그 럼에도 불구하고 유용한 언어이해의 문제점들을 해결할 실마 리들을 힘 주어 말함으로써 독화자들의 언어력의 증진이 일어 나는 학습 효과는 크게 증진되는 일이 일어날 수 있다. 그것은 곧 “입을 열어 말하기”를 함으로써 독화자의 발화기술도 발전 을 기대할 수 있다는 말이다. 바로 이러한 독순독화의 특별한 장점은 수화언어에 세뇌되고 경도된 뛰어난 인지력과 창의력을 지닌 중도 농인은 물론 수화 위주의 농아인들까지도 독화를 통 한 미래를 향한 평생 교육적 재도전을 할 수 있을 가치가 이상 의 논의만으로도 충분히 열려있는 가능성이 있다는 사실을 인 정하지 않을 수 없다.

\section{독화와 발음암시법(cued speech)의 결합법에 의한 교육훈련 과정}

독화(말읽기)는 발음암시법(National Cued Speech Associ$\operatorname{ation}^{\mathrm{TM}}$, 2018)과 결합함으로써 언어이해를 증진한다. 실제 눈 으로는 볼 수 없는 발음상의 섬세한 세부적 신체 동작들을 암 시적으로 상징하는 손짓신호를 독화의 보조수단으로 결합시켜 표현하도록 발화자와 독화자 양쪽을 훈련-교육할 수 있다. 발 음암시법을 함께 활용하는 덕택으로 입는 도움과 논의 중 하나 는 농이나 난청이 아닌 사람들과 의사소통을 하려고 할 때 그 들이 이 발음암시 사인을 사용하지 않는다고 할지라도, 이 발 음암시법이 독회판독자의 독순기술을 높이는 데에도, 청각장애 인의 발어능력을 높이는 데에도 도움이 될 수 있었다는 것이 연구자들이 강력하게 주장하고 싶은 결론이었다. 큐드 스피치는 독화상의 모호성들을 줄이고 조정하는 것을 도와줌으로써, 결 국 독순의 연습과 발음암시법의 사용을 결합함으로써 더 큰 명 료성을 가져오게 되고 발화된 문장들의 이해를 명확하게 한다.

발음암시법과 독화법을 결합한 새로운 교수법의 창안자인 코네트는 워싱턴 갤러뎃 대학에서 일하기 전부터 오랫 동안 독 화법을 연구하였는데, 코네트는 4년간 발음암시법 지도를 했던 18 명의 고심도 농 아동들에게 발음암시법과 독순 그리고 발음 암시법과 독화를 결합한 방식으로 문장명료도를 증진시키기 위한 서로 다른 방법들로 훈련 후 언어이해도를 검사하였는데, 그 결과 이 아동들의 언어명료도는 $95 \%$ 이상의 증진을 나타내
보였다. 거기에서 한 발 더 나아가 같은 방식으로, 청능훈련과 독순에 발음암시법까지 지도한 농 아동들의 문장이해도에 있어 서도 현저한 증진이 이루어졌음을 알 수 있었다. 이 결과는 엄격 하게 독화만으로 지도한 집단이 단어 중 $30 \%$ 정도를 이해한 것 과 비교하면 결합법에 의해 의미 있는 독화명료도의 증진이 이 루어졌음을 알 수 있었고, 농 아동의 교육훈련방법이 앞으로 어 떻게 진행되어야 할지 많은 시사점을 던져주고 있다.

\section{CONCLUSIONS}

위에서 살펴본 논의들은 아래의 논쟁점들(Choi \& Oh, 2015) 을 주도적으로 혹은 부수적으로 좋은 해결 방안을 찾는 데 도 움을 줄 수 있었다고 본다.

1) 시청각적 어음 재인(audio-visual speech recognition) 능 력의 향상

2) 범죄과학수사로서의 독화 판독(forensic speechreading) 능력 훈련 가능성 확장

3) 어음지각의 운동 이론(motor theory of speech perception) 의 실기실습

4) 또박또박 말하기(mouthing)와 자연스럽게 말하기의 차이 와 독화 효율성 측정 방식

5) 내 입술을 읽게 하라(read my lips). 입술 움직임의 차이로 의미를 분명히 구별하게 함(Deafness Cognition and Language Research Centre, 2013)

6) 말읽기 처리과정(reading process)의 도식화

7) 침묵-말하기와의 상호작용(silent speech interface)의 의 미화 과정 향상

8) 복화술(ventriloquism)의 관심과 눈에 보이는 발화에 관 심 증대

9) 시각적 포착(visual capture)의 효율성에 대한 예민한 관찰 력 환기

10) 발음암시법(cued speech)과 독순법의 결합 등의 새로운 착상들을 가능케 함

"주의 깊게 듣는 눈(The Listening Eye: A Simple Introduction to the Art of Lip-Reading) (Clegg, 1953)"이라는 책이나. 미국 $\mathrm{NBC}$ 뉴스의 건강 프로그램 중 아기들이 입술을 읽으며 말하기를 학습하는데, 이것이 자폐장애 문제 해결책의 한 실마 리가 될 수도 있다(NBC News, 2015)는 등을 참조해서 볼 수 있는 관련 분야에 대한 주의 환기의 계기가 되었다고 스스로 평가해 본다. 신생아는 성인의 얼굴 동작들을 흥내 낸다는 연 구결과나, “생명이 있는 곳에 희망이 있다."는 구절들의 독화 오 류 양상들을 음미해 보면 독화의 세계가 얼마나 심오한 명상과 탐구를 통한 지혜와 더불어 특유의 익살과 유머감각까지 고양 
하고 있는지를 새삼 깨닫게 한다. 구화 습득의 가능성은 수화

만으로 교육 받은 농아인 모두에게 $100 \%$ 가능한 일이다. 단지 독화습득능력과 말하기 능력 발전을 성공적으로 교수할 수 있 는 교사가 없다는 것이 문제일 뿐이다(Kim et al., 2009).

중심 단어 : 독화소·한국독화소체계·평생 교육과정.

\section{Ethical Statement}

N/A

\section{Acknowledgments}

N/A

\section{Declaration of Conflicting Interests}

There are no conflict interests.

\section{Funding}

N/A

\section{REFERENCES}

Choi, C. (2008). Audioloy Oral Education. Seoul: School of Korea Oral Education Press.

Choi, C. \& Oh, B. (2015). Education Guidance and Decifering Video 1-13 of Intelligence Officer Qualification Training. Seoul.
Clegg, D. G. (1953). The Listening Eye: A Simple Introduction to the Art of LipReading. New York, NY: Methuen \& Company.

Deafness Cognition and Language Research Centre. (2013, May 11). Read My Lips-Advances in Speechreading Research with Deaf Children. UCL Home. Retrieved from http://www.ucl.ac.uk/dcal/dcal-news/storyll.

Doucet, M. E., Bergeron, F., Lassonde, M., Ferron, P., \& Lepore, F. (2006). Cross-modal reorganization and speech perception in cochlear implant users. Brain, 129(Pt 12), 3376-3383.

Lee, H. (2008). Cerebral functional imaging study of rewarding mechanism-lip reading task for visual communication in post-lingual deaf person (Unpublished doctoral dissertation). Seoul National University Graduate School, Seoul.

Lewkowicz, D. J. \& Hansen-Tift, A. M. (2012). Infants deploy selective attention to the mouth of a talking face when learning speech. Proceedings of the National Academy of Sciences of the United States of America, 109(5), 1431-1436.

National Cued Speech Association ${ }^{\mathrm{TM}}$. (2018, October 8). Retrieved from http://www.cuedspeech.org/.

Kisor, H. (2010). What's That Pig Outdoors?: A Memoir of Deafness. Champaign, IL: University of Illinois Press.

Korea Deaf Education Centennial Memorial Movement. (2009). One Hundred Years of Education for Students with Hearing Impairment in Korea. Seoul, SungKwang.

NBC News. (2015, November 3). Babies Learn to Speak by Lip-Reading, Could Offer Autism Clues. NBC News. Retrieved from http://www. nbcnews.com/health/babies-learn-speak-lip-reading-could-offer-autism-clues-1C6436520. 
APPENDIX

Korea Viseme Pairing Word

\begin{tabular}{llll}
\hline 아-사 & 소-오 & 이-시 & 시-치 \\
북-붓 & 탈-딸 & 발-팔 & 맛-밭 \\
달-날 & 빵-방 & 짱-창-쌍 & 밥-박-발-밤 \\
밤-감 & 밤-삼 & 담-탐-곰 & 실-일-올-울 \\
발-달 & 살-산 & 오-이 & 아-이 \\
갈비-갈피 & 북어-복어 & 사랑-사람 & 담배-담대 \\
칠십-실습 & 구시-육시 & 무시러-무치러 & 삼육-삼구 \\
구상-육상 & 사십만-사심발 & 소라-소가 & 십구-십육 \\
최종-쾌종 & 칠십구팔-칠십구만 & 오이만-오이팔 & 구구-육육 \\
만-팔-발 & 복-봉-불 & 에-어 & 우-에 \\
\hline
\end{tabular}

